\title{
Correction to: Formative research for the design of a scalable water, sanitation, and hygiene mobile health program: $\mathrm{CHoBl} 7$ mobile health program
}

Christine Marie George ${ }^{1 *}$, Fatema Zohura², Alana Teman', Elizabeth Thomas ${ }^{1}$, Tasdik Hasan², Sohel Rana', Tahmina Parvin², David A. Sack', Sazzadul Islam Bhuyian², Alain Labrique', Jahed Masud², Peter Winch', Elli Leontsini', Kelsey Zeller ${ }^{1}$, Farzana Begum², Abul Hasem Khan ${ }^{3}$, Sanya Tahmina ${ }^{3}$, Farazana Munum³, Shirajum Monira ${ }^{2}$ and Munirul Alam²

\section{Correction to: BMC Public Health}

http://dx.doi.org/10.1186/s12889-019-7144-z

It was highlighted that the original article [1] contained an error in the title. Additionally, Table 2 contained a typesetting mistake. This Correction article shows the incorrect and correct article title and Table 2. The original article has been updated.

The Publisher apologizes to the authors and readers for the inconvenience caused by the typesetting mistake.

Incorrect title:

Formative research for the design of a scalable mobile health program water, sanitation, and hygiene: $\mathrm{CHoBI} 7$ mobile health program.

\section{Correct title:}

Formative research for the design of a scalable water, sanitation, and hygiene mobile health program: $\mathrm{CHoBI} 7$ mobile health program.

\footnotetext{
* Correspondence: cmgeorge1@jhu.edu

${ }^{1}$ Department of International Health, Program in Global Disease

Epidemiology and Control, Johns Hopkins Bloomberg School of Public

Health, 615 N. Wolfe Street, Room E5535, Baltimore, MD 21205-2103, USA

Full list of author information is available at the end of the article
}

(c) The Author(s). 2019 Open Access This article is distributed under the terms of the Creative Commons Attribution 4.0 International License (http://creativecommons.org/licenses/by/4.0/), which permits unrestricted use, distribution, and 


\section{Incorrect Table 2 (affected section underlined):}

Table 2 The IBM-WASH Framework Applied to the Development of the CHoBI7 Mobile Health Intervention Based on Qualitative Findings

\begin{tabular}{|c|c|c|c|}
\hline$\frac{\text { BM-WASH }}{\text { Dimension }}$ & Contextual Factors & Psychosocial Factors & Technological Factors \\
\hline $\begin{array}{l}\text { Structural/ } \\
\text { Societal }\end{array}$ & $\begin{array}{l}\text { - Existing government mobile health programs send } \\
\text { out health-related messages on government health } \\
\text { days, these include voice and text mobile messages } \\
\text { - Potential inclusion of CHoBl7 intervention in the } \\
\text { National Operational Plan in Bangladesh } \\
\text { - Potential integration of CHoBI7 in existing mobile } \\
\text { health programs in Banglades }\end{array}$ & $\begin{array}{l}\text { - Government commitment to mobile } \\
\text { health as a method to deliver public } \\
\text { health information }\end{array}$ & $\begin{array}{l}\text { - Existing government mobile platform has the } \\
\text { potential to be used for CHoBI7 intervention delivery } \\
\text { at reduced cost } \\
\text { - Health Education Bureau in the Ministry of Health } \\
\text { and Family Welfare currently develops mobile health } \\
\text { messages, and can be potentially engaged for } \\
\text { CHoBI7 intervention development }\end{array}$ \\
\hline \multirow[t]{2}{*}{ Community } & \multirow{2}{*}{$\begin{array}{l}\text { - High household mobile phone access and } \\
\text { ownership in Bangladesh }\end{array}$} & \multirow{2}{*}{$\begin{array}{l}\text { - Sharing of mHealth messages with } \\
\text { neighbors }\end{array}$} & - High mobile network coverage in Dhaka, Bangladesh \\
\hline & & & $\begin{array}{l}\text { - Most feature phones available in Bangladesh allow } \\
\text { for viewing of Bangla script }\end{array}$ \\
\hline Interpersonal & $\begin{array}{l}\text { - Females in the households are often the ones } \\
\text { responsible for caring for young children } \\
\text { - Male household members may not want female } \\
\text { household members to receive text and voice } \\
\text { messages from an unknown sender }\end{array}$ & $\begin{array}{l}\text { - Female caregivers requesting access } \\
\text { to } \mathrm{CHoBI7} \text { mHealth messages to } \\
\text { allow them to better care for their } \\
\text { children }\end{array}$ & $\begin{array}{l}\text { - Text messages allow for sharing with others at a later } \\
\text { time } \\
\text { - Male household members do not always share } \\
\text { mobile messages or their mobile phones with other } \\
\text { household members } \\
\text { - Timing for mobile message delivery when all } \\
\text { household members are present } \\
\text { - Adult male household members typically have } \\
\text { primary mobile phone ownership in household } \\
\text { - Lower female access to mobile phones }\end{array}$ \\
\hline Individual & $\begin{array}{l}\text { - Literacy rate of household members } \\
\text { - Limited mobile message sharing by those working } \\
\text { outside of the home }\end{array}$ & $\begin{array}{l}\text { - Self-efficacy to open text messages, } \\
\text { and respond to interactive voice } \\
\text { response messages }\end{array}$ & $\begin{array}{l}\text { - Concerns about being charged a fee for viewing or } \\
\text { listening to mobile messages }\end{array}$ \\
\hline Habitual & - Frequency of exposure to mobile messages & $\begin{array}{l}\text { - Outcome expectancy that following } \\
\text { recommendations contained in } \\
\text { mobile messages will reduce } \\
\text { disease }\end{array}$ & $\begin{array}{l}\text { - Voice and text messages as reminders to perform } \\
\text { the promoted water, sanitation, and hygiene } \\
\text { behaviors }\end{array}$ \\
\hline
\end{tabular}

\section{Correct Table 2 (affected section underlined):}

Table 2 The IBM-WASH Framework Applied to the Development of the CHoBI7 Mobile Health Intervention Based on Qualitative Findings

\begin{tabular}{|c|c|c|c|}
\hline $\begin{array}{l}\text { BM-WASH } \\
\text { Dimension } \\
\end{array}$ & Contextual Factors & Psychosocial Factors & Technological Factors \\
\hline $\begin{array}{l}\text { Structural/ } \\
\text { Societal }\end{array}$ & $\begin{array}{l}\text { - Existing government mobile health programs send } \\
\text { out health-related messages on government health } \\
\text { days, these include voice and text mobile messages } \\
\text { - Potential inclusion of CHoBI7 intervention in the } \\
\text { National Operational Plan in Bangladesh } \\
\text { - Potential integration of CHoBI7 in existing mobile } \\
\text { health programs in Bangladesh }\end{array}$ & $\begin{array}{l}\text { - Government commitment to mobile } \\
\text { health as a method to deliver public } \\
\text { health information }\end{array}$ & $\begin{array}{l}\text { - Existing government mobile platform has the } \\
\text { potential to be used for CHoBI7 intervention } \\
\text { delivery at reduced cost } \\
\text { - Health Education Bureau in the Ministry of Health } \\
\text { and Family Welfare currently develops mobile health } \\
\text { messages, and can be potentially engaged for } \\
\text { CHoBI7 intervention development }\end{array}$ \\
\hline \multirow[t]{2}{*}{ Community } & $\begin{array}{l}\text { - High household mobile phone access and ownership } \\
\text { in Bangladesh }\end{array}$ & $\begin{array}{l}\text { - Sharing of mHealth messages with } \\
\text { neighbors }\end{array}$ & $\begin{array}{l}\text { - High mobile network coverage in Dhaka, } \\
\text { Bangladesh }\end{array}$ \\
\hline & & & $\begin{array}{l}\text { - Most feature phones available in Bangladesh allow } \\
\text { for viewing of Bangla script }\end{array}$ \\
\hline Interpersonal & $\begin{array}{l}\text { - Females in the households are often the ones } \\
\text { responsible for caring for young children } \\
\text { - Male household members may not want female } \\
\text { household members to receive text and voice } \\
\text { messages from an unknown sender }\end{array}$ & $\begin{array}{l}\text { - Female caregivers requesting access } \\
\text { to } \mathrm{CHoBI7} \text { mHealth messages to } \\
\text { allow them to better care for their } \\
\text { children }\end{array}$ & $\begin{array}{l}\text { - Text messages allow for sharing with others at a } \\
\text { later time } \\
\text { - Male household members do not always share } \\
\text { mobile messages or their mobile phones with other } \\
\text { household members } \\
\text { - Timing for mobile message delivery when all } \\
\text { household members are present } \\
\text { - Adult male household members typically have } \\
\text { primary mobile phone ownership in household } \\
\text { - Lower female access to mobile phones }\end{array}$ \\
\hline Individual & $\begin{array}{l}\text { - Literacy rate of household members } \\
\text { - Limited mobile message sharing by those working } \\
\text { outside of the home }\end{array}$ & $\begin{array}{l}\text { - Self-efficacy to open text messages, } \\
\text { and respond to interactive voice } \\
\text { response messages }\end{array}$ & $\begin{array}{l}\text { - Concerns about being charged a fee for viewing or } \\
\text { listening to mobile messages }\end{array}$ \\
\hline Habitual & - Frequency of exposure to mobile messages & $\begin{array}{l}\text { - Outcome expectancy that following } \\
\text { recommendations contained in } \\
\text { mobile messages will reduce disease }\end{array}$ & $\begin{array}{l}\text { - Voice and text messages as reminders to perform } \\
\text { the promoted water, sanitation, and hygiene } \\
\text { behaviors }\end{array}$ \\
\hline
\end{tabular}




\section{Author details}

'Department of International Health, Program in Global Disease

Epidemiology and Control, Johns Hopkins Bloomberg School of Public

Health, 615 N. Wolfe Street, Room E5535, Baltimore, MD 21205-2103, USA.

${ }^{2}$ International Centre for Diarrhoeal Disease Research, Bangladesh (icddr,b),

Dhaka, Bangladesh. ${ }^{3}$ Ministry of Health and Family Welfare, Dhaka,

Bangladesh.

\section{Published online: 19 August 2019}

\section{Reference}

1. George, et al. Formative research for the design of a scalable water, sanitation, and hygiene mobile health program: $\mathrm{CHoBl} 7$ mobile health program. BMC Public Health. 2019;19:1028. https://doi.org/10.1186/s12 889-019-7144-z. 